\title{
$2-2-103$ 言語障害昌の聴力検查
}

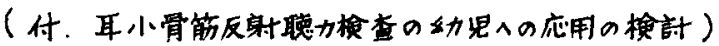

\section{堀口申作。舩木フキ子(東京医科科大学)}

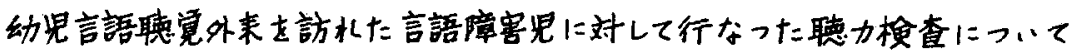

梙討した。 また耳小骨筋反射(Aural Reflex，AR)による㯖力梌查の

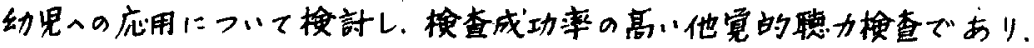

Identification Audiometryとして充分利用できる:とを確認した。

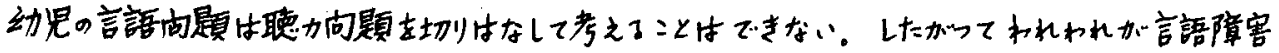

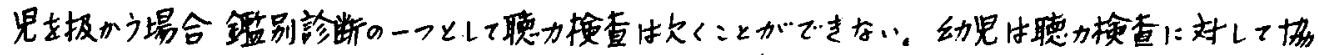

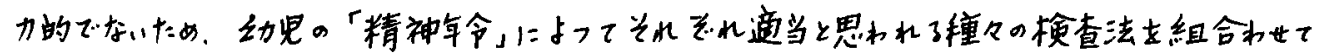

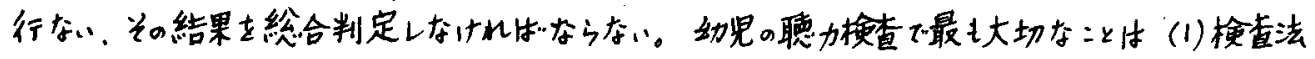

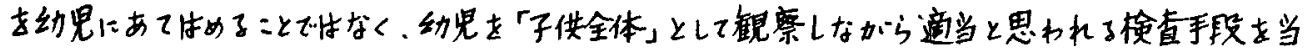
てはめて行くこと(2)純音は幼电にとつて音として意味のないものであるから聴まおとし易く、検查音

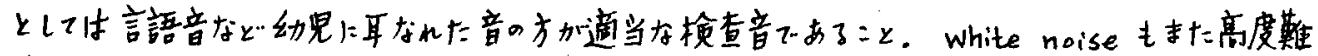
聴あるいは精菭の症例で壮適当な検查音として用いらルることなどである。以上の理由から幼里に

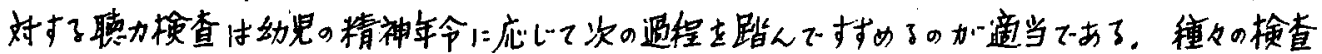

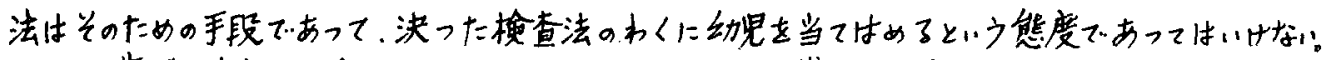

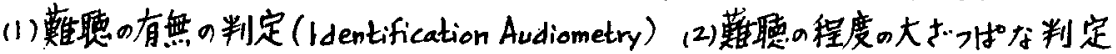

(3)域值の测定

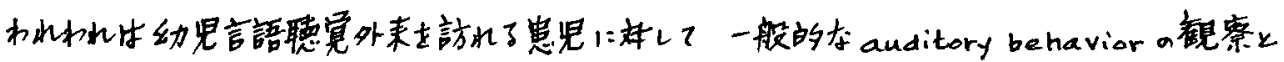
共1: 音場椧直 (Sound Field localization test). COR捡查. Play Audio. Standard

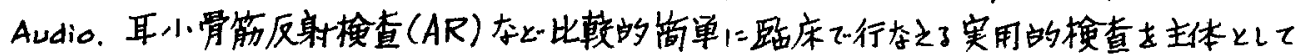
聴力丈検查しているが、最近64月间に当外来を訪れた言語障害兄81例にフいて行なった聴力検查 結果にーいて検討した。

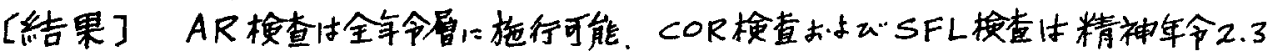

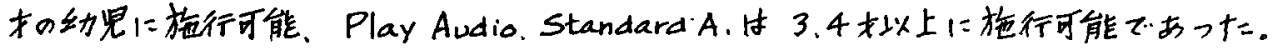

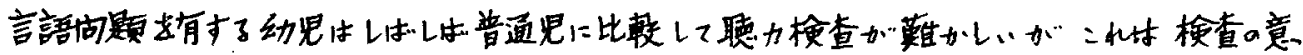
味を理解きせるために检查者が被検者に行なう説明が通じにくい:と、またあるものけ检查音 反応を結でフサるンとができない，落ちつきがなく梌查に注意を集中することができないものが しばし゚みられることなどによる。精菭さ伴なう場合は検查に当フて條件ブけをする:とが殆

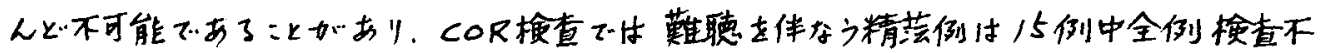

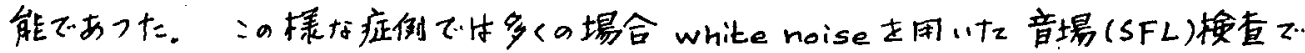
反応(十)、AR検查毛全例施行可能であった。

耳小骨筋反射(AR)検查の幼昌への応用の検計

$A R$ 検查を幼胃に応用した報告は少ない。われわれはの〜14まの57例について検查を行 なったが、Identification Audiometryとして利用価值の広、ものである。装置は思 地教授考案のAR Indicatorを用いた。結果総括すると次の如くである。 
354

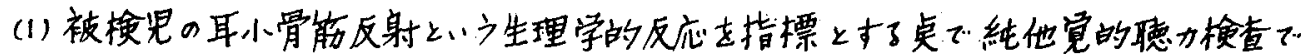

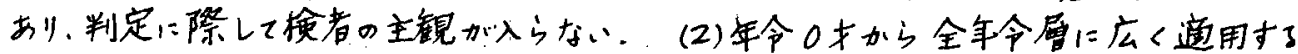
ことが可能である。乙才坎下の幼昌では装置を耳に压定する際動か放よう睡眠剖の

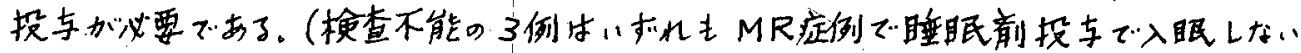
シヒによるものであった。) (3)反応域值が高く70〜110dB (re audiometric 0)aレベル にちり、最小可㯖域值は知ることができず正常上感音難㯖を区别する:とが出来ない。 (4)换查を行なった54例中他の検查て㯖力があるに切かからずAR(ー)例は30\%であった。

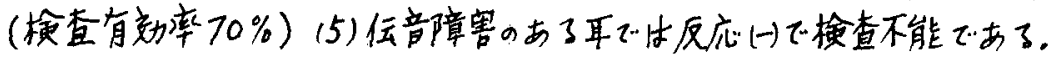

表 1. 言語障害先に対する聴力検查結果(年令别)

\begin{tabular}{|c|c|c|c|c|c|c|c|c|c|c|c|c|c|c|c|}
\hline & \multirow{2}{*}{ 症例数 } & \multicolumn{2}{|c|}{$A R$} & \multicolumn{2}{|c|}{ StartleR. } & \multicolumn{2}{|c|}{ COR } & \multicolumn{2}{|c|}{ SFL } & \multicolumn{2}{|c|}{ Peepshow } & \multicolumn{2}{|c|}{ Play A. } & \multicolumn{2}{|c|}{ Standard } \\
\hline & & 施行 & 不能 & 施行 & 不能 & 施行 & 不能 & 施行 & 不能 & 施行 & 不能 & 施行 & 不能 & 施行 & 不能 \\
\hline $\begin{array}{l}0 \\
1 \\
2 \\
3 \\
4 \\
5 \\
6 \\
7 \\
8 \\
9 \\
10 \\
11 \sim 20\end{array}$ & $\begin{array}{r}1 \\
8 \\
18 \\
17 \\
10 \\
5 \\
9 \\
6 \\
2 \\
2 \\
3\end{array}$ & $\begin{array}{r}1 \\
7 \\
12 \\
11 \\
6 \\
3 \\
7 \\
5 \\
2 \\
2 \\
1\end{array}$ & $\begin{array}{l}2 \\
1\end{array}$ & $\begin{array}{l}4 \\
5 \\
4\end{array}$ & & $\begin{array}{r}1 \\
8 \\
17 \\
9 \\
3 \\
1 \\
3 \\
1 \\
1\end{array}$ & $\begin{array}{l}5 \\
7 \\
6 \\
2 \\
1 \\
2 \\
1\end{array}$ & $\begin{array}{l}5 \\
4 \\
8 \\
3 \\
1 \\
2 \\
1\end{array}$ & 1 & 2 & & $\begin{array}{l}5 \\
4 \\
1 \\
1 \\
2 \\
1 \\
1\end{array}$ & $\begin{array}{l}1 \\
1 \\
2\end{array}$ & $\begin{array}{l}1 \\
3 \\
4 \\
8 \\
4 \\
1 \\
2 \\
2\end{array}$ & ' \\
\hline & 81 & 57 & 3 & 13 & & 44 & 24 & 24 & 1 & 2 & & 15 & 5 & 24 & 3 \\
\hline
\end{tabular}

表 2. 言語障害児に対する聴力检查結果(疾患别)

\begin{tabular}{|c|c|c|c|c|c|c|c|c|c|c|c|c|c|c|c|}
\hline & \multirow{2}{*}{ 症何绕 } & \multicolumn{2}{|c|}{$A R$} & \multirow{2}{*}{\multicolumn{2}{|c|}{$\frac{\text { StartleR. }}{\text { 施行不能 }}$}} & \multicolumn{2}{|c|}{ COR. } & \multicolumn{2}{|c|}{ SFL } & \multicolumn{2}{|c|}{ Peepshow } & \multicolumn{2}{|c|}{ Play A. } & \multicolumn{2}{|c|}{ Standard } \\
\hline & & 施行 & 不能 & & & 施行 & 不能 & 施行 & 不能 & 施行 & 不能 & 施行 & 不能 & 施行 & 不能 \\
\hline Deafn & 6 & $i$ & & 1 & & 4 & 3 & 4 & 1 & & & 1 & & & \\
\hline HOH & 19 & 13 & & 5 & & 10 & 3 & 2 & & & & 1 & & 8 & \\
\hline$M R$ & 51 & 5 & 2 & 1 & & 5 & 2 & 2 & & & & 2 & 1 & 1 & \\
\hline $\begin{array}{l}\text { with } \mathrm{HOH} \\
\text { "Cleft } P \text {. }\end{array}$ & $10\} 22$ & $\begin{array}{r}13 \\
1\end{array}$ & & 4 & & 15 & 15 & 12 & & & & 2 & 1 & I & set. \\
\hline DLL & 7) & 7 & & 1 & & 3 & 1 & & & 2 & & 2 & 1 & 1 & 7 \\
\hline $\begin{array}{l}\text { with } H O H \\
" M R\end{array}$ & $\left.\begin{array}{l|l}2 \\
1\end{array}\right) 10$ & ! & & 1 & & $\begin{array}{l}2 \\
1\end{array}$ & & & & & & 1 & & & \\
\hline Cleft P. & & 1 & & & & $i$ & & 1 & & & & & & 1. & \\
\hline with MR+HoH & $2\} 7$ & 2 & I & & & 1 & & 1 & & & & I & 1 & ? & \\
\hline$C P$ & 2 & & & & & & & & & & & & & 21 & \\
\hline with $\mathrm{HOH}$ & 1 & 1 & & & & & & & & & & 1 & & 1 & \\
\hline $\begin{array}{l}\text { Delayed Sp. } \\
\text { Art. Dis. }\end{array}$ & $\begin{array}{r}2 \\
13\end{array}$ & $\begin{array}{l}.2 \\
8\end{array}$ & & & & $\begin{array}{l}1 \\
1\end{array}$ & & 2 & & & & $\frac{1}{3}$ & 1 & 8 & \\
\hline & & , & & & & & & & & & & & & 11 & \\
\hline & & 157 & 31 & 13 & & 144 & 11 & 24 & 1 & $?$ & & 15 & 5 & 24 & 3 \\
\hline & 01 & 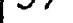 & 3 & & & 147 & 4 & 24 & & 2 & & بر & 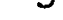 & $<4$ & \\
\hline
\end{tabular}

$S F L$ : sound field localization test. $H O H=$ hard of hearing. $M R$ : mental retardation, DLL: disorder of language learning, Cleft $P_{1}$ : cleft palate $C P$ : cerebral palsy. Dalayed $S_{p}$. = delayed speech. Art. Dis: articulation disorder 